\title{
ÍNDICE DE PROTECCIÓN DEL ENTORNO DE HOGARES EN BOLIVIA ANTE EL COVID-19 SEGÚN LAS RECOMENDACIONES DE LA OMS
}

\section{Lizeth Melina Reyes Dorado Gutiérrez}

\section{RESUMEN}

El presente trabajo evalúa la capacidad de los hogares en Bolivia para seguir las recomendaciones de la OMS y enfrentar al COVID-19 a partir de la elaboración de un índice en base a la metodología planteada por Brown, Ravallion y Van de Walle. Los resultados obtenidos del índice muestran que, existió una mejora considerable desde 2012 con $72.8 \%$ de hogares que tenían las condiciones de protección del hogar respecto a 77\% de los hogares en 2019. La mayor parte de los hogares en Bolivia pueden protegerse del virus con al menos 5 de las 6 recomendaciones de protección básicas sugeridas por la OMS. Se puede observar un importante efecto riqueza, ya que en el área urbana del país las recomendaciones para protegerse de shocks externos como el COVID-19 son más propicias respecto al área rural. Otro resultado muestra que la edad y las condiciones crónicas de salud de las personas las hacen más vulnerables a la presencia de COVID-19 y, lamentablemente sólo un tercio de los hogares puede cumplir con las seis recomendaciones de protección de la OMS. En general, por las condiciones de los entornos de los hogares en Bolivia, las políticas de aislamiento y cuarentena flexible pueden tener éxito en la protección contra el virus.

Palabras Clave: Relación Electricidad -PIB, Cultivos de Coca, Economía Sombra, Economía No Registrada, Bolivia.

DOI: 10.23881/idupbo.021.2-3e 